\title{
Hydrogen Bonding Patterns of Calix[4]arenes with Thiourea Functionalities in Solution and in the Solid State
}

\author{
Su Jeong Kim, Moon-Gi Jo, Jin Yong Lee, ${ }^{\dagger} *$ and, Byeang Hyean Kim* \\ National Research Laboratory, Department of Chemistry, Division of Molecular and \\ Life Sciences, Pohang University of Science and Technology, San 31, Hyoja Dong, \\ Pohang 790-784, Korea. \\ ${ }^{\dagger}$ Department of Chemistry, Chonnam National University, 300 Yongbong-Dong, Bukgu, \\ Gwangju 500-757, Korea \\ bhkim@postech.ac.kr
}

Supporting Information

\section{Contents}

1. General synthetic procedures

2. Synthetic details of $\mathbf{1}, \mathbf{2}$, and $\mathbf{3}$.

3. The HF/6-31G* predicted structures of $\mathbf{1}, \mathbf{2}$, and $\mathbf{3}$.

4. CIF data of $\mathbf{1}, \mathbf{2}$, and $\mathbf{3}$ (separate files). 


\section{General synthetic procedures}

Mps were determined on an Electrothermal IA 9000 series melting point apparatus and are uncorrected. IR spectra were recorded using a Bomem FT-IR spectrometer (PS55+ and DA8). ${ }^{1} \mathrm{H}$ and ${ }^{13} \mathrm{C}$ NMR spectra were taken on a Bruker NMR spectrometer (Aspect $300 \mathrm{MHz}$ ). Chemical shifts $(\delta)$ are reported in ppm and coupling constants $(J)$ in Hz. EI and FAB mass spectra were measured on a KRATOS mass spectrometer (MS 25 RFA) and JEOL four sector tandem mass spectrometer (JMSHX/HX110A). Elemental analyses were done in Center for Biofunctional Molecules (CBM), POSTECH, Korea.

All the chemicals used were obtained from the Aldrich or Lancaster, and used without further purification. All solvents were carefully dried and distilled prior to use. All reactions were carried out with dry glassware under Ar atmosphere. Analytical TLC was carried out on Merck 60 F254 silica gel plate and column chromatography was performed on Merck 60 silica gel (230-400 mesh). 


\section{Synthetic details of 1,2 , and 3 .}

$\underline{\text { Reaction conditions and selected spectroscopic data (compound 1) }}$

Methylisothiocyanate (169 mg, $2.34 \mathrm{mmol}$ ) was added to a solution of 5,17diamino-25,26,27,28-tetrapropoxy calix[4]arene $(740 \mathrm{mg}, 1.19 \mathrm{mmol})$ in $\mathrm{CHCl}_{3}(80$ $\mathrm{mL}$ ) and then the mixture was stirred at room temperature for $3 \mathrm{~h}$. After finishing the reaction, the reaction mixture was added brine and then organic layer was separated, dried over $\mathrm{MgSO}_{4}$. Column chromatography (hexane: ethyl acetate = 3: 1) gave compound 1 (798 mg, 96\%). mp 205.8 - $207.3 \square$; IR ( $\left.\mathrm{KBr}, \mathrm{cm}^{-1}\right) 3250(\mathrm{NH}), 3168$ (ArCH), 2977 (CH), 2930, 3875, 1606, 1517, 1476, 1434, 1396, 1244, 1169, 1111, 1071, 1037, 975, 845, 772; ${ }^{1} \mathrm{H}$ NMR $\left(300 \mathrm{MHz}, \mathrm{CDCl}_{3}\right) \delta 9.63(\mathrm{~s}, 1 \mathrm{H} ; \mathrm{NH}), 7.11(\mathrm{t}, 4 \mathrm{H}, J=$ $7.0 \mathrm{~Hz}$; ArH), 6.96 (t, 2H, J=7.4 Hz; ArH), 5.81 (s, 2H; ArH), 5.45 (s, 2H; ArH), 5.16 $-5.14(\mathrm{~m}, 1 \mathrm{H} ; \mathrm{NH}), 4.42\left(\mathrm{dd}, 4 \mathrm{H}, J_{1}=13.9 \mathrm{~Hz}, J_{2}=24.5 \mathrm{~Hz} ; \mathrm{ArCH}_{2} \mathrm{Ar}\right), 4.06-3.87$ (m, 4H; $\left.\mathrm{OCH}_{2}\right), 3.10\left(\mathrm{dd}, 4 \mathrm{H}, J_{1}=13.9 \mathrm{~Hz}, J_{2}=20.3 \mathrm{~Hz} ; \mathrm{ArCH}_{2} \mathrm{Ar}\right), 2.98(\mathrm{~d}, 3 \mathrm{H}, J=$ $\left.4.6 \mathrm{~Hz} ; \mathrm{NCH}_{3}\right), 1.93-1.81\left(\mathrm{~m}, 8 \mathrm{H} ; \mathrm{CH}_{2}\right), 1.16-1.07\left(\mathrm{~m}, 6 \mathrm{H} ; \mathrm{CH}_{3}\right), 0.85(\mathrm{t}, 6 \mathrm{H}, J=$ $\left.2.5 \mathrm{~Hz} ; \mathrm{CH}_{3}\right) ;{ }^{13} \mathrm{C} \mathrm{NMR}\left(75 \mathrm{MHz}, \mathrm{CDCl}_{3}\right) \delta 207.2,181.5,158.3,155.5,149.4,139.5$, $137.5,136.9,136.0,134.4,130.6,129.6,129.2,127.1,122.4,115.3,77.4,76.6,31.7$, 31.2, 31.1, 23.7, 32.1, 11.1, 11.0, 10.0; MS (FAB, m/z) 695(M+); HRMS (FAB, m/z) $[\mathrm{M}+\mathrm{H}]^{+}$Calcd for $\mathrm{C}_{42} \mathrm{H}_{53} \mathrm{~N}_{3} \mathrm{O}_{4} \mathrm{SNa}, 718.3645$; Found, 718.3652.

$\underline{\text { Reaction conditions and selected spectroscopic data (compound 2) }}$

Methylisothiocyanate $(107.1 \mathrm{mg}, 1.46 \mathrm{mmol})$ was added to a solution of 5,17Diamino-25,26,27,28-tetrapropoxy calix[4]arene (304 mg, $0.488 \mathrm{mmol})$ in $\mathrm{CHCl}_{3}(25$ $\mathrm{mL}$ ). The reaction mixture was heated under reflux for $3 \mathrm{~h}$. After finishing the reaction, the reaction mixture was added brine and then organic layer was separated, dried over 
$\mathrm{MgSO}_{4}$. Column chromatography (hexane: ethyl acetate = 3: 1) gave compound 2 (100 mg, 27\%): mp 258.3 - $259.8 \square$; IR (KBr, cm $\left.{ }^{-1}\right) 3401(\mathrm{NH}), 3201(\mathrm{ArCH}), 2961(\mathrm{CH})$, $2874,1541,1464,1385,1345,1252,1218,1126,1056,1006,964,889,766 ;{ }^{1} \mathrm{H}$ NMR $\left(300 \mathrm{MHz}, \mathrm{CDCl}_{3}\right) \delta 7.13(\mathrm{~s}, 2 \mathrm{H} ; \mathrm{NH}), 7.09(\mathrm{~d}, 4 \mathrm{H}, J=7.4 \mathrm{~Hz} ; \mathrm{ArH}), 6.95(\mathrm{t}, 2 \mathrm{H}, J=$ $6.9 \mathrm{~Hz}$; ArH), 6.12 - 6.10 (m, 2H; NH), 6.04 (s, 4H; ArH), 4.45 (d, 4H, J = $13.3 \mathrm{~Hz}$; $\left.\mathrm{ArCH}_{2} \mathrm{Ar}\right), 4.04-3.99\left(\mathrm{~m}, 4 \mathrm{H} ; \mathrm{OCH}_{2}\right), 3.70\left(\mathrm{t}, 4 \mathrm{H}, J=6.9 \mathrm{~Hz} ; \mathrm{OCH}_{2}\right), 3.17(\mathrm{~d}, 4 \mathrm{H}, J=$ 13.4 Hz; $\left.\mathrm{ArCH}_{2} \mathrm{Ar}\right), 2.95$ (d, 6H, $\left.J=4.6 \mathrm{~Hz} ; \mathrm{NCH}_{3}\right), 2.00-1.85\left(\mathrm{~m}, 8 \mathrm{H} ; \mathrm{CH}_{2}\right), 1.10(\mathrm{t}$, $\left.6 \mathrm{H}, J=7.4 \mathrm{~Hz} ; \mathrm{CH}_{3}\right), 0.90\left(\mathrm{t}, 6 \mathrm{H}, J=7.4 \mathrm{~Hz} ; \mathrm{CH}_{3}\right) ;{ }^{13} \mathrm{C} \mathrm{NMR}\left(75 \mathrm{MHz}, \mathrm{CDCl}_{3}\right) \delta$ $181.9,157.7,154.2136 .8,135.5,131.3,129.3,123.6,122.8,77.5,77.4,31.9,31.3,23.7$, 23.1 10.9, 10.0; MS (FAB, m/z) 768(M+), 770, 1028, 921, 875, 736,663, 632, 460, 392, 307, 220; HRMS (FAB, m/z) $[\mathrm{M}+\mathrm{H}]^{+}$Calcd for $\mathrm{C}_{44} \mathrm{H}_{57} \mathrm{~N}_{4} \mathrm{O}_{4} \mathrm{~S}_{2}, 769.3821$; Found, 769.3821.

$\underline{\text { Reaction conditions and selected spectroscopic data (compound 3) }}$

1,1'-Thiocarbonyldiimidazole (38.4 $\mathrm{mg}, 0.216 \mathrm{mmol})$ was added to a solution of compound $1(300 \mathrm{mg}, 0.431 \mathrm{mmol})$ in THF $(50 \mathrm{~mL})$ and then the mixture was stirred at room temperature for $1 \mathrm{~h}$. After finishing the reaction, the reaction mixture was added brine and then organic layer was separated, dried over $\mathrm{MgSO}_{4}$. Column chromatography (hexane: ethyl acetate $=3: 1)$ gave compound $3(217 \mathrm{mg}, 70 \%)$. mp 256.4 - $257.9 \square$; IR (KBr, cm$\left.{ }^{-1}\right) 3400(\mathrm{NH}), 3211(\mathrm{ArCH}), 2961(\mathrm{CH}), 2932,2874$, $1598,1537,1462,1384,1343,1257,1216,1127,1064,1005,965,886,762,636 ;{ }^{1} \mathrm{H}$ NMR $\left(300 \mathrm{MHz}, \mathrm{CDCl}_{3}\right) \delta 8.40(\mathrm{~s}, 2 \mathrm{H} ; \mathrm{NH}), 8.21(\mathrm{~s}, 2 \mathrm{H} ; \mathrm{NH}), 7.15$ - 7.09 (m, 8H; ArH), 6.99 (t, 4H, J = 7.3 Hz; ArH), 6.20 (s, 4H; ArH), 5.89 (s, 4H; ArH), $5.50-5.60$ $(\mathrm{m}, 2 \mathrm{H} ; \mathrm{NH}), 4.42\left(\mathrm{dd}, 8 \mathrm{H}, J_{1}=13.7 \mathrm{~Hz}, J_{2}=15.7 \mathrm{~Hz} ; \mathrm{ArCH}_{2} \mathrm{Ar}\right), 4.03-3.98(\mathrm{~m}, 8 \mathrm{H}$; 
$\left.\mathrm{OCH}_{2}\right), 3.69-3.64\left(\mathrm{~m}, 8 \mathrm{H} ; \mathrm{OCH}_{2}\right), 3.14\left(\mathrm{dd}, 8 \mathrm{H}, J_{1}=13.5 \mathrm{~Hz}, J_{2}=25.7 \mathrm{~Hz}\right.$; $\left.\mathrm{ArCH}_{2} \mathrm{Ar}\right), 3.03\left(\mathrm{~d}, 6 \mathrm{H}, J=4.5 \mathrm{~Hz} ; \mathrm{NCH}_{3}\right), 1.98-1.82\left(\mathrm{~m}, 16 \mathrm{H} ; \mathrm{CH}_{2}\right), 1.14-1.06(\mathrm{~m}$, $\left.12 \mathrm{H} ; \mathrm{CH}_{3}\right), 0.86\left(\mathrm{t}, 12 \mathrm{H}, \mathrm{J}=7.4 \mathrm{~Hz} ; \mathrm{CH}_{3}\right) ;{ }^{13} \mathrm{C} \mathrm{NMR}\left(75 \mathrm{MHz}, \mathrm{CDCl}_{3}\right) \delta 181.8,178.3$, $157.2,152.5,152.3,136.8,135.8,135.2,132.9,132.6,130.3,129.1,128.2,124.1,122.3$, 119.8, 76.7, 76.0, 31.4, 30.6, 30.4, 29.2, 23.1, 23.0, 22.4; MS (FAB, m/z) 1437( $\left.{ }^{+}\right)$, 1404, 1329, 1255, 1168, 930, 845, 739, 666, 663, 460; HRMS (FAB, m/z) $[\mathrm{M}+\mathrm{H}]^{+}$ Calcd for $\mathrm{C}_{85} \mathrm{H}_{105} \mathrm{~N}_{6} \mathrm{O}_{8} \mathrm{~S}_{3}, 1433.7156$; Found, 1433.2163 . 


\section{The HF/6-31G* predicted structures of 1,2 , and 3 .}

For 1, there are four different conformational isomers, syn-anti (1sa), anti-syn (1as), anti-anti (1aa), and syn-syn (1ss), depending on the dihedral angles between $\mathrm{N}$ Me and $\mathrm{C}=\mathrm{S}$ and between $\mathrm{N}-\mathrm{Cal}$ and $\mathrm{C}=\mathrm{S}$ where $\mathrm{Cal}$ represents Calix[4]arene, in thiourea group (Figure S1). Among these isomers, 1sa is predicted to be the most stable conformer, which has lower energy than the others by about $4.4 \mathrm{kcal} / \mathrm{mol}$, which is consistent with the crystal structures. The relative energies of 1sa, 1ss, 1aa, and 1as are 0, 4.42, 4.76, and $4.95 \mathrm{kcal} / \mathrm{mol}$, respectively. Syn conformation between C=S and NMe is favored by methyl hydrogen-sulfur interactions, and anti conformation between $\mathrm{C}=\mathrm{S}$ and $\mathrm{N}-\mathrm{Cal}$ by additional amine hydrogen-aromatic interactions.

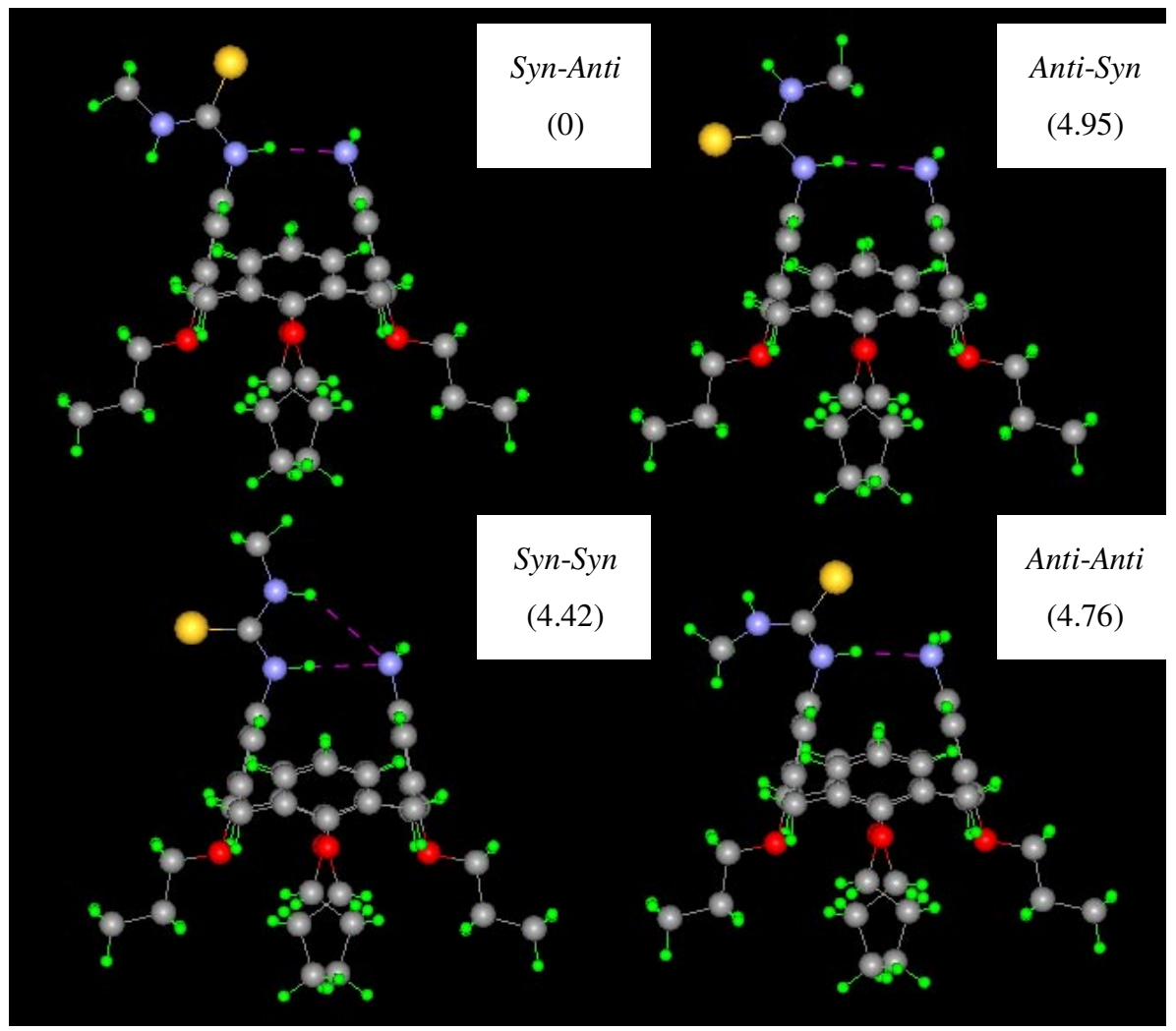

Figure S1. HF/6-31G* optimized structures of four conformers of 1 and their relative energies (in $\mathrm{kcal} / \mathrm{mol}$ ) in parentheses. 
For 2 , both thiourea moieties are expected to have syn-anti confomrations as in 1. In this condition, closely positioned thiourea groups are repulsive and repell each other to give $\mathbf{2 a}$ as in the crystal which has different calix[4]arene topology from $\mathbf{1}$ (Figure S2). As another possible confomer (2b), we choose that one thiourea moiety has syn-anti conformation, and the other one has syn-syn so that it can have intramolecular H-bonding between two thiourea groups keeping the same calix[4]arene topology as in 1. $\mathbf{2 b}$ is calculated to be more stable than $\mathbf{2 a}$ by about $2 \mathrm{kcal} / \mathrm{mol}$ because of the intramolecular H-bond, and this type of conformer was reported in earlier work. In solid state, however, two intermolecular H-bonds are operating per 2a molecule, while one intermolecular H-bond per $\mathbf{2 b}$. Overall, $\mathbf{2 a}$ or $\mathbf{2 b}$ can be preferred in crystal formation in a certain condition. As a matter of fact, in our experimental condition, 2a was crystallized.

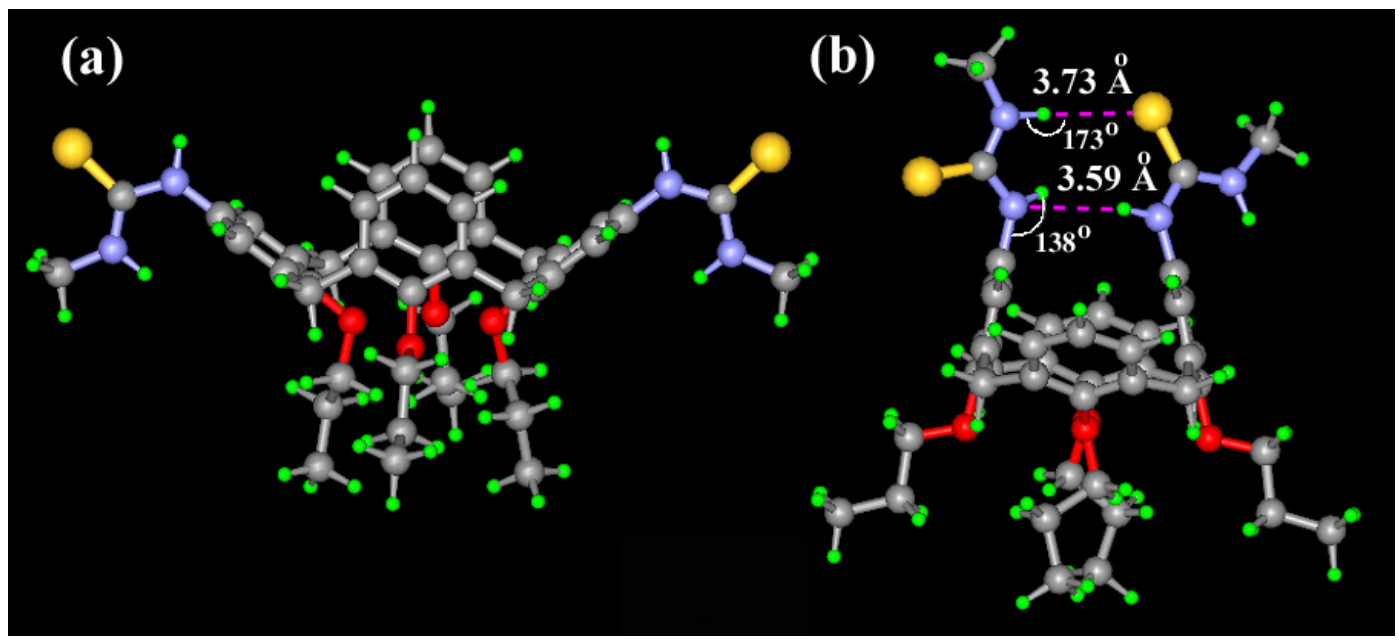

Figure S2. (a) 2a: X-Ray crystal structure. (b) 2b: HF/6-31G* optimized structures of conformer (Compound 2). 
For 3, there are three thiourea moieties, one for bridge and two for terminals. The calculated structure is virtually equivalent to the crystal one. Four intramolecular $\mathrm{H}$-bonds are in action, two between $\mathrm{NH}$ of bridge thiourea and two $\mathrm{S}$ atoms of terminal thioureas and two between two Cal-NH of terminal thioureas and two $\mathrm{S}$ atoms of terminal thioureas. That is, the bridge thiourea plays as two protons donor and the terminal thioureas play as both proton donor and acceptor. This compound is very rigid due to the cross-linked intramolecular H-bonds, and has the same calix[4]arene topology as $\mathbf{1}$.

\begin{tabular}{|lll|}
\hline \multicolumn{2}{|c|}{$\mathrm{D}(\mathrm{S} \ldots \mathrm{H}) \square(\mathrm{S} \ldots \mathrm{H}-\mathrm{N}) \mathrm{d}(\mathrm{S} \ldots \mathrm{N})$} \\
\hline $2.761 \AA$ & $160.3^{\circ}$ & $3.722 \AA$ \\
\hline $2.539 \AA$ & $168.9^{\circ}$ & $3.532 \AA$ \\
\hline $2.779 \AA$ & $159.5^{\circ}$ & $3.736 \AA$ \\
\hline $2.547 \AA$ & $169.5^{\circ}$ & $3.541 \AA$ \\
\hline
\end{tabular}

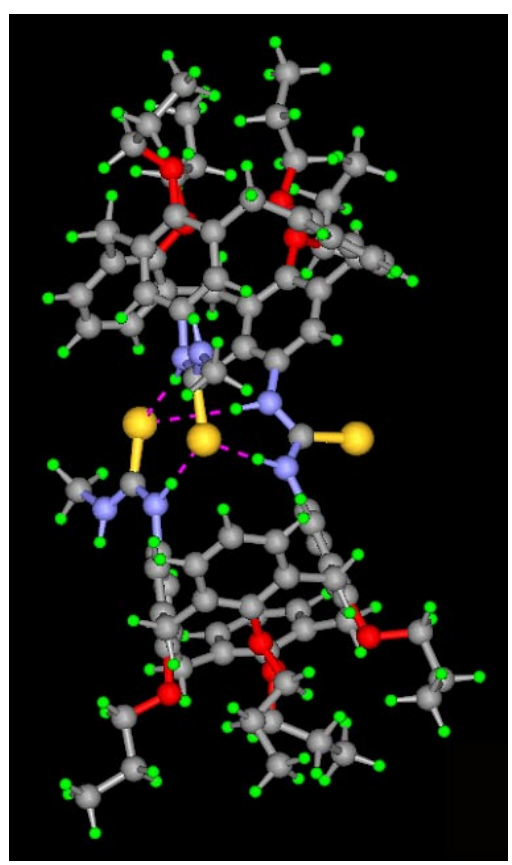

Figure S3. HF/6-31G* optimized structures of $\mathbf{3}$ and calculated data.

In order to look into the nature of interactions, NMR spectra have been analyzed. ${ }^{1} \mathrm{H}$ NMR spectrum shows dramatic changes depending on the interaction nature. The calculated NMR spectra are virtually equivalent with experimental spectra (Figure S4). Based on the calculated ${ }^{1} \mathrm{H}$ spectra, we can assign the peaks and note the 
effects of interactions on the changes. The simulated characteristic ${ }^{1} \mathrm{H}$ NMR chemical shifts of $\mathrm{Ha}, \mathrm{Hb}, \mathrm{Hc}, \mathrm{Hd}, \mathrm{He}, \mathrm{Hf}$, and $\mathrm{Hg}$ (See scheme 1 for notation) appear at 7.51, $2.86,5.78,3.11,6.24,7.64$, and $4.37 \mathrm{ppm}$, respectively, which are in good agreement with experimental data of $9.65,5.11,6.12,3.43,8.22,8.42$, and $5.64 \mathrm{ppm}$. Intramolecular hydrogen bonds in $\mathbf{1}$ and $\mathbf{3}$ lead the chemical shifts to much downfielded. We found the NMR peaks at 6.12 and $3.43 \mathrm{ppm}$ (Figure 5) for Hc and Hd in $\mathbf{2 a}$ due to the absence of intramolecular H-bond.

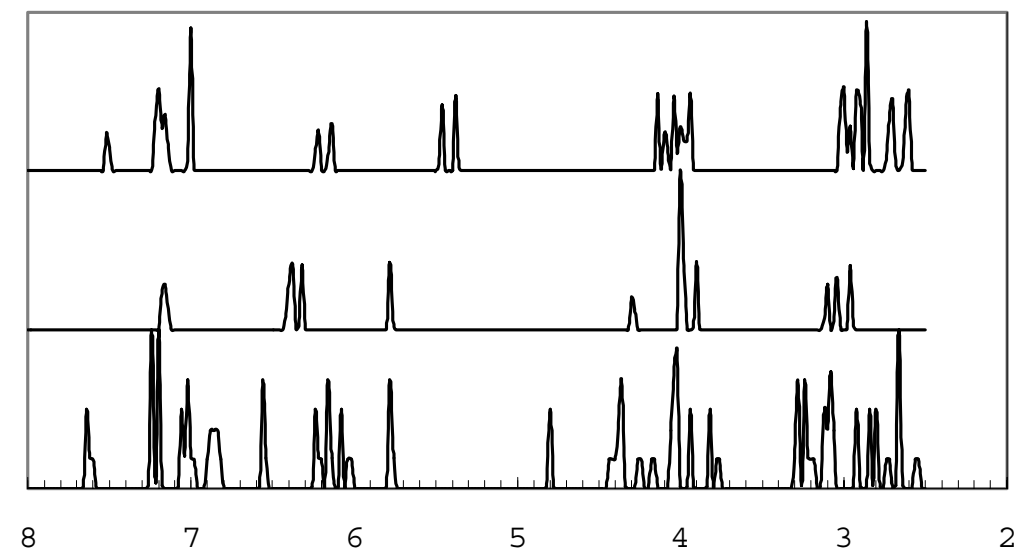

Figure S4. Calculated NMR spectra of $\mathbf{1}$ (top), 2a (middle), and $\mathbf{3}$ (bottom). 